\title{
Teacher cognition: A powerful phenomenon developing and governing habits of teaching
}

\author{
Mustafa Öztürk (D) \\ Hacettepe University, School of Foreign Languages, Ankara, Turkey, mustafaozturk@ hacettepe.edu.tr
}

ABSTRACT Teaching has a complex feature being both a cognitive activity as well as a social behavior; thus, it is highly crucial to monitor how teachers develop and govern their habits and behavioral tendencies in the classroom. Teachers' mental government has been the focus of educational research for a long time, because it is known to drive their actions. Considering teacher cognition as a powerful asset to develop and govern the habits of teaching, this paper adopts a conceptual review approach and presents a comprehensive and integrated literature review on teacher cognition along with its historical basis, key components, conceptual domains, origins, and driving forces. Building upon the empirical and theoretical literature compiled over a four-decade period, the paper presents a tripartite model regarding the conceptual domains of teacher cognition. As it is influenced by contextual circumstances surrounding teachers' personal and professional lives, the concept of teacher cognition is revisited with regard to three origins and three driving forces. In this regard, the paper reconsiders teacher cognition in terms of the ways it is constructed and the ways it is oriented to action, and finally concludes with implications for teacher education.

Keywords: Teacher belief, Teacher cognition, Teacher knowledge, Teacher thinking

\section{Öğretmen bilişi: Öğretmenlik alışkanlıklarını geliştiren ve yöneten güçlü bir olgu}

ÖZ Öğretmenlik, hem bilişsel bir etkinlik hem de sosyal bir davranış olarak karmaşık bir özelliğe sahiptir; bu nedenle, öğretmenlerin sınıftaki alışkanlıklarını ve davranışsal eğilimlerini nasıl geliştirdiğini ve yönettiğini izlemek son derece önemlidir. Öğretmenlerin zihinsel yönetimi uzun süredir eğitim araştırmalarının odak noktası olmuştur, çünkü bu zihinsel yönetimin onların eylemlerini yönlendirdiği bilinmektedir. Öğretmen bilişini öğretmenlik alışkanlıklarını geliştirmek ve yönetmek için güçlü bir olgu olarak gören bu makalede, kavramsal geliştirme yaklaşımı benimsenmiş ve öğretmen bilişi tarihsel temelleri, kilit bileşenleri, kavramsal boyutları, temel kökenleri ve itici güçleriyle birlikte ele alınarak kapsamlı ve bütüncül bir alanyazın derlemesi sunulmuştur. Kırk yılı aşkın bir dönemi kapsayan deneysel ve kuramsal alanyazın üzerine inşa edilmiş bu çalışmada, öğretmen bilişinin kavramsal alanlarına ilişkin üçlü bir model ortaya konmaktadır. Öğretmenlerin kişisel ve mesleki yaşantılarını çevreleyen bağlamsal koşullardan etkilendiği için, öğretmen bilişi kavramı üç temel köken ve üç itici güç açısından yeniden değerlendirilmektedir. Bu bağlamda, makale öğretmen bilişini inşa edilme ve eyleme yönelme biçimleri açısından yeniden ele almakta ve son olarak öğretmen eğitimi için öneriler sunmaktadır.

$\begin{aligned} & \text { Anahtar } \text { Öğretmen bilgi sistemi, Öğretmen bilişi, Öğretmen düşünce sistemi, Öğretmen inanç sistemi } \\ & \text { Sözcükler: }\end{aligned}$

Citation: $\quad$ Öztürk, M., (2021). Teacher cognition: A powerful phenomenon developing and governing habits of teaching. Turkish Journal of Education, 10(2), 178-194. https://doi.org/10.19128/turje.801945 


\section{INTRODUCTION}

Studying teachers' thought processes has attracted increasing interest in the last four decades. The primary goal of the studies has been to describe cognitive psychology of teaching with its all aspects and make it available for educational theorists, researchers, policymakers, curriculum designers, teacher educators, school administrators, and teachers themselves to use. (Clark \& Peterson, 1986). The concern has generally been to portray what elements, visible or invisible, constitutes teachers' working lives. The visible aspect is related to what teachers actually do for teaching, such as classroom interactions, task implementations, material designing procedures, assessment processes, and so on. They all merge under the concept of 'teacher action.' The invisible aspect includes beliefs, values, perspectives, expectations, judgements, knowledge, thoughts, emotions, and so on. And, they are all conceptualized as a part of 'teacher cognition' (Öztürk \& Yıldırım, 2019).

Central to this paper are the questions of what teacher cognition is, why it is crucial, and how it evolves. Having both internal and external bases, teachers' habits of teaching are the truest reflections of their personal, social, and professional development. Teaching habits are critically important, because they could either facilitate or hinder learning and teaching processes. In view of the fact that teaching has a complex feature being both a cognitive activity as well as a social behavior, it is highly crucial to monitor how teachers develop and govern their teaching habits and behavioral tendencies. In this regard, teachers' mental government has been the focus of educational research for a long time, because it is thought to drive their actions. That is to say, teachers develop and govern their actions with the help of their cognitions. Seeing teacher cognition as a powerful asset, it is essential to look into the concept with its historical basis, key components, conceptual domains, origins, and driving forces.

\section{The Approach}

This paper adopted a conceptual review approach through which a comprehensive and integrated literature review on teacher cognition was presented, a conceptual landscape with all underlying factors, dimensions and relationships was drawn, and integrated frameworks and models were offered. In order to map out the conceptual landscape of the topic, the paper basically looked into the "what, how, and why' of teacher cognition, as Whetten (1989) suggests. Accordingly, it aimed to clarify which factors, variables, constructs or concepts should be considered as part of the explanation, how they are related, and what underlying dynamics justify those relationships. Within this framework, the following steps were taken to develop a logical and complete argument: (1) compiling a variety of empirical and theoretical literature (Hirshcheim, 2008); (2) providing a summary of recent research on the construct (Gilson \& Goldberg, 2015); (3) "underscoring commonalities that build coherence" (Cropanzano, 2009, p. 1306); (4) integrating and proposing new relationships among constructs (Gilson \& Goldberg, 2015); and (5) adding a value as a contribution to the extant literature (Short, 2009).

As a result of those steps, the paper first presents historical basis and key components of teacher cognition, provides the last decade's empirical studies, and offers a tripartite model for conceptual domains. Next, the paper discusses three origins and three driving forces of teacher cognition by focusing on contextual circumstances surrounding teachers' personal and professional lives. And finally, the paper reconsiders teacher cognition in terms of the ways it is constructed and the ways it is oriented to action and concludes with implications for teacher education. The added value of this paper is, in particular, an integrated discussion of (a) origins and driving forces of teacher cognition as well as (b) construction and orientation aspects of teacher cognition. 


\section{Historical Basis of Teacher Cognition}

Regarding the cognitive basis of teaching, study of teacher cognition and its impact on educational practices started to emerge four decades ago. As an important step under the standpoint of teacher thinking, Clark and Yinger (1977) identified cognitive perspectives as: planning, judgment, decisionmaking, and implicit theories of teachers. At the beginning of 1980s, Shavelson and Stern (1981) presented a review on teachers' pedagogical thoughts, judgments, and decisions by claiming that a behavioral focus on teaching without considering teachers' cognitions is incomplete. As they suggested, if knowledge is not available, teachers rely on beliefs for guidance. Afterwards, practical knowledge, a concept covering the kind of knowledge that teachers hold and use, emerged in the case study of Elbaz (1983), who affirmed that teachers' instructional practices are guided by their feelings, values, needs, beliefs, experiences, theoretical knowledge, and folklore.

In the second half of 80s, Clark and Peterson (1986) categorized their review on teacher thinking around the following dimensions: teacher planning; teachers' interactive thoughts and decisions; and teachers' theories and beliefs. According to them, the interaction between teacher thoughts and teacher behaviors are crucial, because "the process of teaching will be fully understood only when these two domains (thought and behaviors) are brought together and examined in relation to one another" (p. 258). Clandinin and Connelly (1986) focused on the construct of personal practical knowledge, which was portrayed mostly through personal philosophies and metaphors. Accordingly, a teacher's personal philosophy was discussed to cover beliefs and values derived from experience and form a unity among beliefs, values, and actions. Metaphors, similarly, were said to reflect teachers' way of thinking and acting about teaching. Later, they defined personal practical knowledge as a "moral, affective, and aesthetic way of knowing life's educational situations" (Clandinin \& Connelly, 1987, p. 59). This definition underlined dialectical, situated, and dynamic sides of teachers' knowledge, which could be reconstructed and reshaped through a constant interaction with experiences. For them, teacher belief and teacher knowledge were included in the concept of personal practical knowledge, which stands for how a teacher understands a classroom situation. However, Nespor (1987) made a distinction between belief and knowledge and provided four features of beliefs to distinguish it from knowledge: (a) existential presumption, which stands for personal truth about learners and learning; (b) alternativity, which refers to conceptualizations of ideal situations differing significantly from present realities; (c) affective and evaluative loading, which makes beliefs be expressed in the form of feelings, moods, subjective evaluations and personal preferences; and (d) episodic structure, which is based on particular, well-remembered events.

According to Thompson (1992), it is unnecessary to make a distinction between beliefs and knowledge particularly in definitions, because what is more critical is to realize how these concepts affect what teachers do. Similarly, Kagan (1992) used the terms 'beliefs' and 'knowledge' interchangeably when analyzing methodological issues. Pajares (1992) put forward the difficulty in studying teachers' beliefs because of definitional problems, poor conceptualizations, and differing understandings about beliefs and belief structures and therefore examined the meaning given to beliefs by various influential researchers. It was further clarified that teachers' beliefs have a greater influence than teachers' knowledge on their decision-making, planning, classroom implementations, and attitude towards students. Fenstermacher (1994) focused on teacher cognition from an epistemological perspective and used the concept of teacher knowledge as a classifying term grouping other constructs like beliefs and conceptions under it.

At the beginning of 90s, Carter (1990) focused on what teachers know and how that knowledge is gained. To answer this question, three concepts were arranged under teacher knowledge: (a) information processing; (b) practical knowledge; and (c) pedagogical content knowledge. According to Carter, teachers' practical knowledge is "shaped by a professional's personal history, which includes intentions and purposes, as well as the cumulative effects of life experience" (p. 300). Ball and McDiarmid (1990) dealt with research on subject-matter knowledge and subject-matter preparation of teachers. Subsequently, research on subject-specific teacher cognition emerged. 
The two landmark publications in the second half of the 90s were (a) Richardson's (1996) work in Handbook of Research on Teacher Education, which focused on the roles of attitudes and beliefs in learning to teach and (b) Calderhead's (1996) work in Handbook of Educational Psychology, which examined research on teachers' beliefs and knowledge. Richardson (1996) noted that students might bring beliefs to teacher education programs, which are personal experience, school experience, and experience with formal knowledge, and therefore they might affect their learning to teach. At the same time, changes in students' beliefs as an effect of teacher education programs were addressed. Calderhead (1996) classified the domains in teacher cognition as: decision-making; perceptions and evaluations; and knowledge and beliefs. Under the concept of teacher knowledge, the following subcategories appeared: subject knowledge, craft knowledge, personal practical knowledge, case knowledge, theoretical knowledge, metaphors, and images. Under the concept of teacher belief, the following sub-categories appeared: beliefs about learners and learning, beliefs about teaching, beliefs about subject, beliefs about learning to teach, and beliefs about self and teacher role.

As an important milestone, Woods (1996) published the book titled Teacher Cognition in Language Teaching: Beliefs, Decision-making and Classroom Practice, through which the term BAK representing a hypothetical concept of an integrated network of beliefs, assumptions and knowledge was introduced and discussed extensively. As indicated in the book, knowledge, assumptions, and beliefs do not refer to distinct concepts, but to "points on a spectrum of meaning", and so "they may overlap with each other" (p. 195). Accordingly, the term knowledge refers to what teachers know, in other words conventionally accepted facts that have been and could be demonstrated. The term assumption, on the other hand, represents the temporary acceptance of a fact that has not been demonstrated before, but taken as true for the time being. The term belief is an acceptance of a proposition which does not reflect conventional and demonstrable knowledge, but might have an accepted disagreement.

Borg (1998), in his qualitative study, focused on the term 'teachers' personal pedagogical systems', which cover stores of beliefs, knowledge, theories, assumptions, and attitudes, as well as its key role in shaping teachers' instructional decisions. He also highlighted the importance of studying the factors that influenced the development and application of personal pedagogical systems. Later, he used the term 'teacher cognition' as a sum of "the beliefs, knowledge, theories, assumptions, and attitudes that teachers hold on all aspects of their work" (Borg, 1999, p. 95). Wenden (1999), on the other hand, defined beliefs as a subset of meta-cognitive knowledge by suggesting that "beliefs are distinct from meta-cognitive knowledge in that they are value-related and tend to be held more tenaciously" (p. 436).

Research interest in study of teacher cognition in the $2^{\text {nd }}$ millennium has also continued and increased. Verloop et al. (2001) attached importance to studying teacher cognition for educational innovations, because "in the mind of the teacher, components of knowledge, beliefs, conceptions, and intuitions are inextricably intertwined" (446). In the light of this perspective, they claimed that teacher knowledge was both strongly related to individual experiences and contexts and also shared by large groups of teachers teaching at a certain level. Therefore, understanding of teacher knowledge might be useful to improve teacher education and to make educational innovations more effective.

A comprehensive review of 64 studies conducted on teacher cognition between the years 1970 and 2002 was provided by Borg (2003). He discussed different teacher belief terminologies and conceptualized teacher cognition as the central schema which plays a critical role in teachers' lives. The concept of teacher cognition was addressed through its connection with prior learning experience, teacher education and classroom practice. As he redefined, teachers' cognition represents "the unobservable cognitive dimension of teaching - what teachers know, believe, and think" (p. 81). With Borg (2006), language teacher cognition research has become an established domain of inquiry in language teaching research, and his book titled Teacher Cognition and Language Education: Research and Practice has taken a fundamental role specifically in leading the research on language teaching contexts. In this direction, Zheng (2009) provided a summary of empirical research on EFL pre- 
service teachers' beliefs and practices in 1990s and 2000s through a discussion about the concept of belief. Accordingly, the concept of 'belief' was described to "embrace the complexity of teachers' mental lives underlying their practices (p. 74).

More recently, a special issue was published in the Modern Languages Journal in 2015 in order to redraw the boundaries of teacher mind and cognition in the context of language teaching. A lot of concepts were discussed in the issue. Teaching-mind, like all forms of thinking, was associated with "part and parcel of people in activity in a particular time and place" (Burns et al., 2015, p. 596), and cognitions were asserted to be integrated with emotions, both of which are activated in and shaped by the interactions occurring in learning-to-teach experiences (Golombek, 2015).

Focusing on science teachers' cognitions, Hutner and Markman (2016) proposed a complimentary model of cognition, which specifically highlights the existence of social influences on the cognition of individuals and the introspective feature of the cognitive development. In this way, they suggested that teacher cognition is shaped by social and implicit factors. Later, Hutner and Markman (2017) suggested a goal-driven model of teacher cognition, which is claimed to play a significant role in resolving two anomalies: (a) the early-stage teachers' tendency to discard innovative pedagogies taught in initial teacher education programs and adopt traditional approaches; and (b) the discrepancy between all stage teachers' self-reported pedagogical orientations and observed behaviors exhibited in the classroom. Accordingly, teachers' goals are depicted as mental constructs that reflect their motivational and behavioral system, and thus teachers' instructional practices are a way of fulfilling their goals. Burri et al. (2017) discussed teachers' identity construction and cognitive development as intertwined in a complex and reciprocal relationship. As asserted in their article, teachers' identity was constructed through the imagination of the self and the others as well as their engagement with their subject matter and content, and the process of identity construction exerts a profound impact on teachers' cognitions.

During the same years, Li (2017) mentioned cognition as "socially and publically displayed understanding, knowing, positioning, conceptualizing and stance-taking" (p. 56) and suggested examining it through the lens of social interaction and discursive psychology, especially in professional contexts. Her latest publication on teacher cognition $(\mathrm{Li}, 2020)$ pointed out the significance of sociocultural perspective when demonstrating how teachers learn in professional communities and how their experiences contribute to their thinking, understanding, conceptualizations, and beliefs. Once again, the link between teacher cognition and sociocultural interactions within teachers' lives was highlighted.

As depicted in the aforementioned literature compiled over a four-decade period, teacher cognition is by and large the interplay between being and becoming a teacher and it has close connections with three major concepts: beliefs, knowledge and thinking.

\section{Last Decade's Empirical Studies on Teacher Cognition}

The empirical studies conducted in the last decade covered a wide range of topics investigated pertaining to teacher cognition. For instance, Mori (2011) focused on how teachers' cognitions shape their feedback practices and concluded that factors such as instructional focus, time constraints, student profile, school context, and prior experiences of teachers as learners play crucial roles in shaping their cognitions. Hong (2012), on the other hand, looked into teacher cognition regarding teaching approaches and discovered that teachers never adopt solely one approach and they are mainly under the influence of their own classroom experiences during prior schooling and pre-service years. In this direction, Attia (2014) explored the role of early learning experiences on teacher cognition, in particular about technology use, and asserted that the conceptions of 'good' or 'bad' teaching habits were formed during prior schooling and teacher education could exert a mediating effect on teachers' initial conceptualizations or pedagogical theories. 
In the study of Walsh and Wyatt (2014), teachers' methodological principles and teaching practices were researched with respect to contextual factors. Although the practices were usually consistent with the methodological principles and general educational goals, there were also difficult contextual factors, such as tests and cultural assumptions, ahead of those principles. Using the dynamic systems theory to examine teacher cognition, Feryok and Oranje (2015) investigated teachers' adoption of an innovative practice (a cultural portfolio) and discovered that a teacher usually adopt such an innovation by conceptualizing it through possible practical challenges involved in that particular innovation.

Lim (2016) studied teacher cognition from a sociocultural perspective in a multicultural and multilingual context. In the study, teachers' emic perspectives were linked to their selfacknowledgement, perceived teaching goals, teaching approaches, and attitudes towards to the subject matter. Gök-Kaça and Yiğitoğlu (2017) worked on teachers' challenges, confusions and tensions when putting the pre-set curriculum objectives into practice and reported the fact that how curriculum could become a hindrance for teachers and prevent them from acting in line with their own cognitions. Karimi and Norouzi's (2017) focus was how to support cognitive development of novice teachers and put forward that teachers' pedagogical knowledge base and thought units could grow as a consequence of expert mentoring initiatives. Accordingly, teachers' cognitions could significantly differ between their pre-mentoring and post-mentoring status. According to Ngo (2018), changes in a teacher's cognition follows a complex, non-linear path. These shifts involve dialectical relationships and mediating resources such as humans, concepts, and artifacts.

Ghasemi (2018) addressed teachers' cognitive dissonance, its impact on their practices, and how teachers cope with such a tension. A remarkable finding was that novice and expert teachers could both experience cognitive dissonance throughout their careers. It was also underlined that the incongruence between cognitions and actions could hinder teachers' professional development. Mohammadabadi et al. (2019) examined the factors influencing teacher cognition from an ecological systems perspective. As they claimed, teaching equipment, teachers' mood and feelings, and their job satisfaction could influence their cognitions at microsystem level while governmental policies and attitudes as well as relationships with students affect the cognitions at macrosystem level. On the other hand, teachers' self-efficacy, prior learning experiences, collaboration and collegiality with other teachers in the same school along with critical incidents happening in the school could influence their cognitions at mesosystem level; whereas teacher appraisal criteria, curriculum, and teacher immunity are other influential factors at exosytem level.

As in the study of Alzaanin (2019), teachers' cognitions could influence their teaching approaches, curriculum design, and assessment methods, and the ecological context could occur as a mediating force influencing the interaction between cognitions and practices. In particular, the classroom context could become a more significant barrier. Still, the teachers working in the same context under the same conditions could exhibit different teaching habits, which could result from another critical factor: teachers' cognitions about themselves as professionals. Sun et al. (2020) also tried to measure implicit attitudes of teachers and highlighted that teachers could reflect different degrees of implicit or explicit attitudes and all those differences could be attributed to the personal, institutional, and social contexts in which they were teaching.

\section{Conceptual Domains of Teacher Cognition}

The breadth and depth in the descriptions covered in the literature of the last four decades could be represented through a tripartite model in which the three key pillars are portrayed as teacher belief, teacher knowledge, and teacher thinking (see Figure 1). 
Figure 1.

Conceptual Domains of Teacher Cognition

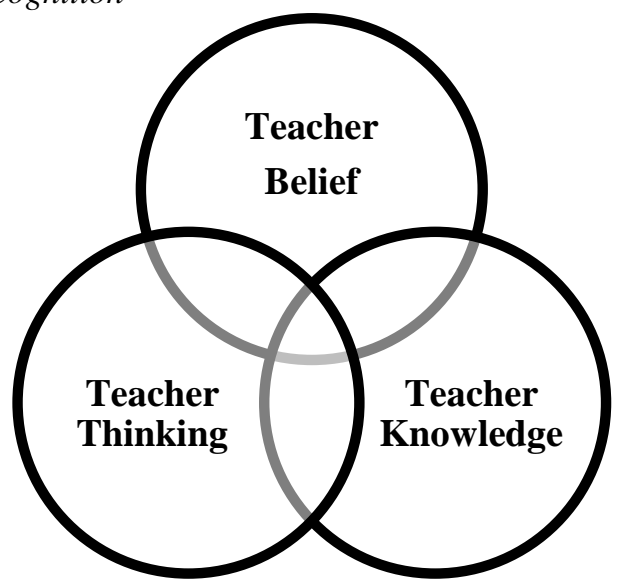

\section{Teacher belief}

The first pillar, teacher belief, is constructed and developed through an abundant number of elements which help teachers become ethical, effective, and professional educators. As Woods (1996) asserts, a belief system is related "not only with the way things are, but also with the way things should be" (p.70); hence, decisions leading to actions are derived mostly from beliefs about what is good and bad in the current state. Similarly, beliefs are claimed to be psychologically held understandings, premises, or propositions that are accepted as true by the individuals holding the beliefs (Richardson, 1996), which highlights the personal and experiential aspects of beliefs. Thompson (1992) also draws attention to the dynamic feature of belief systems by defining them as "permeable mental structures" and suggesting that they are "susceptible to change in light of experience" (p. 140).

The volume of research investigating teacher cognition has led the researchers to focus mostly on 'belief' component, and this resulted in an immense amount of educational research about teacher belief. Richardson (1996) defines beliefs as "a sub-set of a group of constructs that name, define, and describe the structure and content of mental states that are thought to drive a person's actions" ( $p$. 102). Therefore, beliefs, as a psychological construct, have always been an essential concern for studying teaching and teacher education. In relation to the scope of teachers' educational beliefs, Pajares (1992) presents an inclusive list of words related to beliefs:

attitudes, values, judgments, axioms, opinions, ideology, perceptions, conceptions, conceptual systems, preconceptions, dispositions, implicit theories, explicit theories, personal theories, internal mental processes, action strategies, rules of practice, practical principles, perspectives, repertoires of understanding, and social strategy (p. 309).

Johnson's (1994) assumptions about teachers' beliefs wonderfully summarize the significance of studying teacher belief as an educational phenomenon:

(1) teachers' beliefs influence both perception and judgment which, in turn, affects what teachers say and do in classrooms; (2) teachers' beliefs play a critical role in how teachers learn to teach, that is, how they interpret new information about learning and teaching and how that information is translated into classroom practices; and (3) understanding teachers' beliefs is essential to improving teaching practices and professional teacher preparation programs (p. 439).

\section{Teacher knowledge}

As for the second pillar, teaching is such a complex activity that it requires different kinds of cognitive and practical knowledge. Having various aspects, knowledge base of teaching is tracked usually through domains of content, pedagogical, practical, or technological aspects. Early literature on 
teacher knowledge attached importance to teachers' content knowledge (Ball \& McDiarmid, 1990). Then, teachers were expected to know and demonstrate the subjects they teach including all the concepts, evidences, facts, ideas, procedures, rules, and theories within a particular field. Later, general pedagogy, independent of a specific teaching field, gained importance in professional coursework (Leinhardt \& Smith, 1985). Accordingly, all the processes and methods practiced in teaching to ensure learners' learning and achievement were emphasized. Regarding what teachers should know, Shulman (1987) introduced the combination of the two components and portrayed how content knowledge and pedagogical strategies automatically interacted in teachers' minds. Thenceforth, pedagogical content knowledge is proposed to be mastered jointly by teachers.

In the same line with beliefs, teachers' knowledge is a critical part of teachers' competence that influences teachers' development as well as learners' progress. This knowledge is thought to be dialectical, situated, and dynamic, and hence it could be reconstructed and reshaped (Clandinin \& Connelly, 1987). The strength of this knowledge is also gained through experience, which brings about the concept of practical knowledge. Teachers' practical knowledge is claimed to be situational, theoretical, personal, social, experiential contextualized, task-specific and event-structured (Carter, 1990). Meijer et al. (1999) listed the characteristics of teachers' practical knowledge as: personal and unique; contextual and adapted to classroom situation; based on and developing through experience; tacit; guiding for practice; content-related and connected with subject; and resulting from professional activity. Accordingly, they put forward three types of practical knowledge: subject-matter knowledge, student knowledge, and knowledge of student learning and understanding.

Nowadays, teacher education is shifting its focus primarily to technology-enhanced teaching, which made teachers' technological knowledge an essential domain (Moreland et al., 2001). Currently, teacher knowledge is a kind of interplay of all those components, and TPCK (Technological Pedagogical Content Knowledge) model particularly indicates a dynamic relationship between knowledge of content, pedagogy, and technology (Koehler \& Mishra, 2005).

\section{Teacher thinking}

Regarding the final pillar, the picture of teacher thinking is also multifaceted. Teacher thinking is related to teachers' abilities of adaptability, flexibility, problem solving, logical deduction, generalization and conceptualization on the basis of their personal and professional observations and inquiries. Teachers are viewed as active thinkers who are able analyze teaching, improve practice, and construct their identity from their own experiences (Zeichner, 1994). For about a half century, teachers' intellectual functioning and mental government have been the focus of educational research, and teachers' thinking styles were attributed to have some sort of connections with teachers' actions in the classroom.

As the most complex stage in cognitive development, teacher thinking is explained through a wide range of styles in literature. According to Sternberg (1997), there exist 13 thinking styles and they are classified into five dimensions: (a) functions like including legislative, executive, and judicial styles, (b) forms as hierarchical, monarchic, oligarchic, and anarchic styles, (c) levels like global and local styles), (d) scopes like internal and external styles, and (e) leanings such as liberal and conservative styles.

In the study of McAlpine et al. (2006), four 'zones' of thinking were depicted through the following terms: (1) conceptual thinking, as the most abstract of all, comprises abstract statements or beliefs in relation to teaching and resembles the notion of 'conceptions'; (b) enactive thinking, as the most concrete of all, represents thinking in-the-moment of action; (c) strategic thinking and (d) tactical thinking, both of which appear between conceptions and actions and are akin to the 'approaches' to teaching. 


\section{DISCUSSION}

As implied by the literature covered in the preceding sections of the paper, teacher cognition does not necessarily reflect clear cut or straightforward orientations; it rather reveals complex and dynamic features (Öztürk \& Yıldırım, 2015) and it is difficult to detect and measure through explicit methods (Sun et al., 2020). For this reason, the question of how teacher cognition evolves could be explained through a variety of sources and as a result of multiple interactions with those sources.

\section{Origins and Driving Forces of Teacher Cognition}

As the origins and driving forces of teacher cognition, Figure 2 presents three elements for each construct. Accordingly, prior schooling, initial teacher education, and in-service classroom experience are the three basic sources that teachers' cognitions are originated in. These sources have an extensive coverage in the literature on teacher cognition.

Figure 2.

Origins and Driving Forces of Teacher Cognition

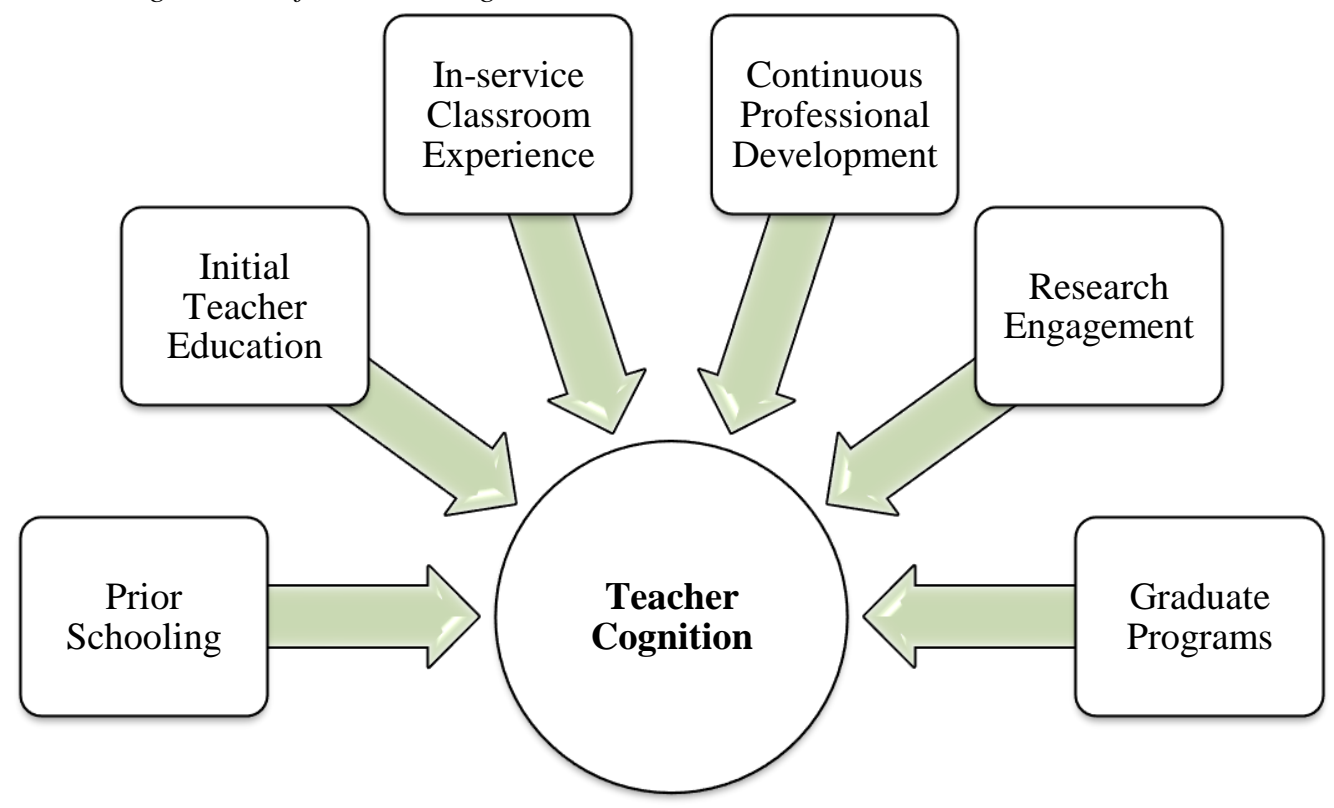

Prior schooling, as 'the first' of all, refers to early experiences of teachers as young students in schools. Those experiences often create powerful and influential images of what teaching should be like in the minds of teachers. Sometimes it is difficult for individuals to alter the images of teachers and teaching that they construct in their prior schooling, because those images (positive or negative) are usually formed as a result of interactions with former teachers and close observations of prior classroom environments. Considering the influence of earlier school settings where teachers are raised and schooled, it is highly acceptable that teacher candidates could possess prior cognitions formed much before coming to initial teacher education programs, and their pre-existing schema for teaching are rooted in their earlier learning experiences. The influence stemming from previous educational experiences is addressed and emphasized in a lot of studies and articles (Attia, 2014; Borg, 2003; Carter, 1990; Decker \& Rimm-Kaufman, 2008; Elbaz, 1983; Hong, 2012; Johnson, 1994; Mohammadabadi et al., 2019; Mori, 2011). It is also suggested that prior cognitions could be too strong or complicated to change (Gupta, 2004; Nespor, 1987; Pajares, 1992) and student teachers possibly use their preconceived beliefs about teaching and learning as filters for their subsequent learning during teacher education (Kagan 1992; Richardson, 1996).

Initial teacher education, as a central period for the formation of teachers' professional identities, is 
discussed to be a strong major source from which teacher cognitions are directly derived. Many papers focus on the potential impact of initial training programs, courses, practicum, or teaching practices occurring in pre-service years (Borg, 1998, 2003; Guskey, 2002; Hong, 2012; Johnson, 1994; Mattheoudakis, 2007; Ng et al., 2009). In this framework, initial teacher education has inevitable influences on teachers' cognition (Li, 2020), because their cognitive change and growth occur as a result of the philosophies and approaches inherited from their teacher educators as well as the interactions with their peers. Both of the sources have fundamental and undeniable roles in shaping teachers' visions. What is also possible, during initial teacher education, is that teacher candidates gain new visions while they keep their pre-established beliefs intact (Attia, 2014; Thomas \& Pedersen, 2003).

Another central role is given to experiences obtained from actual classroom practices, because classroom experience in one way or another influence or contribute to the formation of teacher cognition (Borg, 2003; Feryok \& Oranje; 2015). As contributors of teacher development, teachers' authentic interactions with students shape their knowledge and thought processes significantly, and their prior beliefs or pre-established cognitions might change over time as they interact with their students in their own classrooms. At this point, the priorities in a teacher's personal and professional life determine or shape his or her beliefs to a great extent, because they are closely related to the meaning(s) that he or she assigns to teaching and how they define the classroom life. Sometimes they are the results of a teaching experience or a continuous engagement with learners, because practice is an effective mode of guidance for the construction, reconstruction, and destruction of beliefs. There are also other factors that might ease this formation, such as educational culture and school climate. In this respect, contextual factors might explain why certain teachers adopt certain approaches in certain settings, because contextual variables are emphasized in almost all the papers discussing the sources of teacher cognition (Alzaanin, 2019; Borg, 2003; Fang, 1996; Gök-Kaça \& Yiğitoğlu, 2017; Grisham, 2000; Grossman, 1990; Li, 2020; Meijer et al., 1999; Mohammadabadi et al., 2019; Sun et al., 2020; Walsh \& Wyatt, 2014).

As for the driving forces that are likely to create, form, shape, and modify cognitions about teaching in later stages, continuous professional development, research engagement, and graduate programs are the other three elements (see Figure 2). However, these are not sufficiently addressed in the literature on teacher cognition or not as much as the other three origins discussed above.

Teachers' cognitions are possible to be strengthened through continuous professional development, which fosters interaction-rich activities, discussions and experiences and thus becomes an important driving force of cognitions. The changes happening in teachers' knowledge, belief and thinking with the help of continuous professional development could also have the potential to improve their teaching (Guskey, 2002; Karimi \& Norouzi, 2017; McCutchen et al., 2002).

Research engagement could also be a wonderful way of involving in self-reflection, self-evaluation, and self-direction, all of which would lead teachers to review and update their existing mindset. There are a lot of studies acknowledging the benefit of engaging with research (Flores, 2018). To be more specific, with the help of teacher research, teachers could establish their own cognitions about the practical sides of teaching, such as what works and why it works (Cordingley, 2003; Ponte et al., 2004), update their critical and reflective attitudes (Hall, 2009), and gain autonomy and ownership of their own work (Todd et al., 2004). Through all those processes teachers could turn out to be potential creators and producers of knowledge of how to teach.

As a further stage, graduate programs or courses are believed to contribute to teachers' thought, belief, and knowledge structures. Although it is not widely and deeply examined in previous research, the impact of graduate education and graduate programs could also be significant to change teachers' orientations, beliefs, and understandings in relation to teaching (Öztürk \& Yıldırım, 2015). It is an explicable proposal that teachers pursuing graduate studies could regenerate their knowledge and belief systems, and this regeneration could come from each and every element of a graduate program. 
Everything considered, all the origins and driving forces could also interact with each other and contribute to the formation of teachers' cognitive development, and it is typical that teacher cognition is not rooted in a single isolatable source.

\section{Construction and Orientation Aspects of Teacher Cognition}

Building upon a vast variety of empirical and conceptual studies done on teacher cognition so far, we could reconsider teacher cognition in terms of the two aspects of it: construction aspect and orientation aspect. Looking at the first aspect, the ways teacher cognition is constructed, we could consider two simple ways: experiential construction through which teachers reflect on what they do as a teacher and use their own experience as a basis; and observational construction which occurs by virtue of observing or modeling other teachers around. In both ways, cognition construction depends on teachers' consciousness of what they see, hear, read, do, ask and answer within the self or with others.

Considering that teacher cognition has a complex characteristic that does not arise only from the individual nor from the environment alone, but from the interaction of both, we should address and appreciate both 'self-generated' and 'externally-acquired' cognitions of teachers as well as the interaction between the teacher and the environment. In this framework, self-generated teacher cognition is constructed as a result of the teacher's internally-focused mental activity and is usually independent of external input. On the other hand, 'externally-acquired teacher cognition' has a significant place, too, because there is always a possibility to show teachers new alternatives or approaches to guide their teaching habits. In this way, teachers are likely to embrace new cognitions or confront their existing cognitions, and as a result, they critically analyze them and transform them into new perspectives. Since cognitions could mediate between internal states and external input, this process appears as an essential stage of constructing or reconstructing teacher cognition and refers to an intersection between self-generated and externally-acquired cognitions.

Conceptualizing teacher cognition as a powerful asset to govern teaching habits and considering its behavior-regulating function, we could look into the second aspect, the ways it is oriented to action by addressing functional, non-functional, and situational cognitions of teachers (see Figure 3 ).

Figure 3.

Orientation Aspect of Teacher Cognition

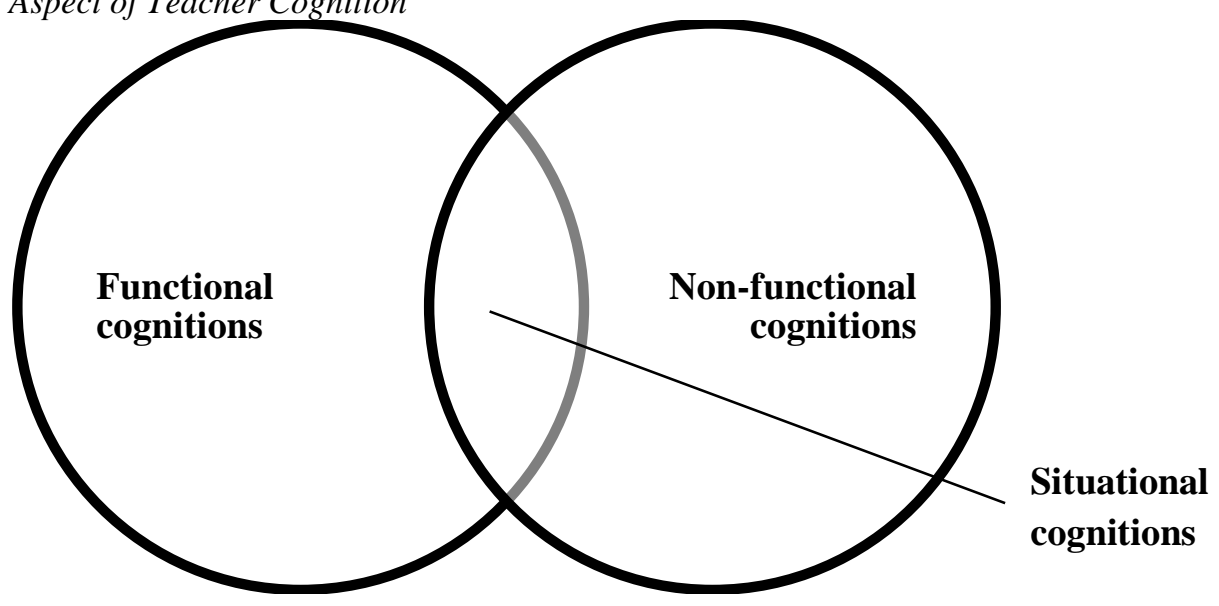

Functional cognitions, in essence, are appropriately transferrable to action. In other words, they are practice-oriented, and this orientation refers to the capacity of cognitions to regulate behaviors. In an appropriate transfer of cognitions into educational actions, teachers are expected to do or act in the same way as they believe or think. And thus, they eliminate the possibility of the dissonance between cognition and action. However, non-functional cognitions cause teachers to experience such a dissonance, because they fail in regulating or modifying behaviors. Since non-functional cognitions might reduce teachers' willingness to perform in certain ways or prevent them from fulfilling their 
intentions, the gap between cognition and action grows. Therefore, teacher cognition's being persuasive enough to turn into actions might explain its behavior-regulating function.

As Figure 3 depicts, there exist also situational cognitions, which are a mixture of functional and nonfunctional ones. Sometimes teachers' sensations, perceptions and attentions might vary in different circumstances at different times, and the transfer of cognitions into actions might be dependent on those occasions. At this point, environmental dynamism and intra-personal dynamism appear to be two critical components of decision making, reasoning, and judgment of teachers. While environmental dynamism refers to possible differences observed in educational settings, intra-personal dynamism refers to possible differences observed within the same teacher at different times or in different situations. Considering either dynamism as well as the combination of both, some cognitions of teachers are possible to be situational.

\section{CONCLUSION AND IMPLICATIONS}

Considering the mutual influences between cognitions and behavioral intentions, which in turn influence actions and actual practices, conducting educational research on teacher cognition contribute to teacher education in four ways: (1) presenting precious information for the content of teacher education; (2) providing teacher educators with insights so that they could think on the instructional methods of teacher education; (3) creating and directing educational policies that are relevant to teacher education, and (4) improving introspection and reflectivity of teachers on their teaching habits.

As an implication, teacher educators should focus on how to respond to prospective teachers' cognitions coming from prior experiences. Their strategies should move beyond the assumptions that prior cognitions will interfere with what they offer to teacher candidates. They should become effective observers of particular situations to elicit underlying cognitions that matter most for the content and implementation of the pre-service programs in initial teacher education. They should inquire their own practices, study their students in particular situations, and develop practical theoretical frames of how pre-service teachers learn to teach.

As stated in many studies, teachers' cognitions cannot be static or unchangeable, because cognitive development has such a dynamic feature and emergent aspects that it is possible to observe changes in cognitions over a period of time through certain interactions. Teachers are capable of using their knowledge to change their teaching practices. Taking this proposition into account, designing inservice trainings as continuous professional development activities are good ways to update practicing teachers about the latest developments and innovations in education and thus promote necessary cognitive and behavioral changes in them. When designing their teaching to be able to create effective learning environments, teachers rely on their own assumptions or knowledge about learning and teaching, therefore; positive impacts of in-service trainings on teachers' thinking and acting styles would be inevitable.

Seeing reflectivity as a tool for in-service teachers to confront their own cognitions and reflect on their cognitive and behavioral orientations when teaching, introspection, which stands for teachers' consciousness of what they are doing when they follow certain habits of teaching, provides us with a road to understand teaching with covert dynamics embedded in it. Considering the fact that teaching cannot be examined solely through observing behaviors and rather more focus on cognitive sides ought to be given, there is a fundamental component of quality teaching: the concept of 'cognition' that refers to unobservable cognitive dimensions of teachers, especially in relation to what they think of, believe in, know about and understand from learning and teaching. In the same way, it stands for the distillation of teaching practices routinely performed by teachers as a result of their gains from prior learning, pre-service and in-service trainings, and in-class teaching experiences. All those factors have significant effects on teachers' learning and development. Therefore, the integrated review 
provided in this paper is a good basis for presenting a better understanding about the educational practices of teachers as well as leading professional development activities within pre-service and inservice contexts of teacher education.

\section{REFERENCES}

Alzaanin, E.I. (2019). An exploratory study of the interplay between EFL writing teacher cognition and pedagogical practices in the Palestinian University Context. Arab World English Journal, 10(3), 113-132.

Attia, M. (2014). The role of early learning experience in shaping teacher cognition and technology use. In P. Breen (Ed.), Cases on teacher identity, diversity and cognition in higher education (pp. 1-21). IGI Global.

Ball, D.L., \& McDiarmid, G.W. (1990). The subject-matter preparation of teachers. In W. R. Houston (Ed.), Handbook of research on teacher education (pp. 437-449). Macmillan.

Borg, S. (1998). Teachers' pedagogical systems and grammar teaching: A qualitative study. TESOL Quarterly, 32(1), 9-38.

Borg, S. (1999). Studying teacher cognition in second language grammar teaching. System, 27(1), 19-31.

Borg, S. (2003). Teacher cognition in language teaching: A review of research on what language teachers think, know, believe, and do. Language Teaching, 36(2), 81-109.

Borg, S. (2006). Teacher cognition and language education: Research and practice. Continuum.

Burns, A., Freeman, D., \& Edwards, E. (2015). Theorizing and studying the language teaching mind: Mapping research on language teacher cognition. The Modern Language Journal, 99(3), 585-601.

Burri, M., Chen, H., \& Baker, A. (2017). Joint development of teacher cognition and identity through learning to teach L2 pronunciation. The Modern Language Journal, 101(1), 128-142.

Calderhead, J. (1996). Teachers: Beliefs and knowledge. In D. C. Berliner \& R. C. Calfee (Eds.), Handbook of educational psychology (pp. 709-725). Macmillan.

Carter, K. (1990). Teachers' knowledge and learning to teach. In W. R. Houston (Ed.), Handbook of research on teacher education (pp. 291-310). Macmillan.

Clandinin, D.J., \& Connelley, F.M. (1986). Rhythms in teaching: The narrative study of teachers' personal practical knowledge of classrooms. Teaching and Teacher Education, 2(4), 377-387.

Clandinin, J.D., \& Connelly, M.F. (1987). Teachers' personal knowledge: what counts as personal in studies of the personal. Journal of Curriculum Studies, 19, 487-500.

Clark, C.M., \& Peterson, P.L. (1986). Teachers' thought processes. In M. C. Wittrock (Ed.), Handbook of research on teaching ( $3^{\text {rd }}$ ed.) (pp. 255-96). Macmillan.

Clark, C., \& Yinger, R. (1977). Research on teacher thinking. Curriculum Inquiry, 7(4), 279-304.

Cordingley, P. (2003). Research and evidence-based practice: Focusing on practice and practitioners. In L. Anderson \& N. Bennett (Eds.), Developing educational leadership: Using evidence for policy and practice (pp. 104-114). Sage Publications.

Cropanzano, R. (2009). Writing nonempirical articles for Journal of Management: General thoughts and suggestions. Journal of Management, 35, 1304-1311.

Decker, L.E., \& Rimm-Kaufman, S.E. (2008). Personality characteristics and teacher beliefs among pre-service teachers. Teacher Education Quarterly, 35(2), 45-64.

Elbaz, F. (1983). Teacher thinking: A study of practical knowledge. Croom Helm.

Fang, Z. H. (1996). A review of research on teacher beliefs and practices. Educational Research, 38(1), 47-65.

Fenstermacher, G.D. (1994). The knower and the known: The nature of knowledge in research on teaching. Review of Research in Education, 20, 1-54.

Feryok, A., \& Oranje, J. (2015). Adopting a cultural portfolio project in teaching German as a Foreign Language: Language Teacher Cognition as a Dynamic System. The Modern Language Journal, 99(3), 546-564.

Flores, M.A. (2018). Linking teaching and research in initial teacher education: Knowledge mobilisation and research-informed practice. Journal of Education for Teaching, 44(5), 621-636.

Ghasemi, F. (2018). Iranian EFL teacher cognition: Tracing cognitive dissonance. The Journal of Language Teaching and Learning, 8(2), 61-79.

Gilson, L.L., \& Goldberg, C.B. (2015). Editors' comment: So, what is a conceptual paper? Group \& Organization Management, 40, 127-130.

Golombek, P.R. (2015). Redrawing the boundaries of language teacher cognition: Language teacher educators' emotion, cognition, and activity. The Modern Language Journal, 99(3), 470-484.

Gök-Kaça, G., \& Yiğitoglu, N. (2017). Influences of curriculum on novice teacher cognition: Help or a hindrance? Australian Journal of Teacher Education, 42(9), 1-22. 
Grisham, D.L. (2000). Connecting theoretical conceptions of reading to practice: A longitudinal study of elementary school teachers. Reading Psychology, 21(2), 145-170.

Grossman, P. (1990). The making of a teacher: Teacher knowledge and teacher education. Teachers' College.

Gupta, R. (2004). Old habits die hard: Literacy practices of pre-service teachers. Journal of Education for Teaching, 30(1), 67-78.

Guskey, T.R. (2002). Professional development and teacher change. Teachers and Teaching: Theory and Practice, 8(3), 381-391.

Hall, E. (2009). Engaging in and engaging with research: Teacher inquiry and development. Teachers and Teaching: Theory and Practice, 15(6), 669-81.

Hirshcheim, R. (2008). Some guidelines for the critical reviewing of conceptual papers. Journal of the Association for Information Systems, 9, 432-441.

Hong, N.C. (2012). Teacher cognition and grammar teaching approaches. Southeast Asia: A Multidisciplinary Journal, 12, 17-31.

Hutner, T., \& Markman, A. (2016). Department-level representations: A new approach to the study of Science teacher cognition. Science Education, 100(1), 30-56.

Hutner, T.L., \& Markman, A.B. (2017). Applying a goal-driven model of science teacher cognition to the resolution of two anomalies in research on the relationship between science teacher education and classroom practice. Journal of Research in Science Teaching, 54(6), 713-736.

Johnson, K.E. (1994). The emerging beliefs and instructional practices of pre-service ESL teachers. Teaching and Teacher Education, 10(4), 439-452.

Kagan, D. (1992). Implications of research on teacher beliefs. Educational Psychologist, 27, 65-90.

Karimi, M. \& Norouzi, M. (2017). Scaffolding teacher cognition: Changes in novice L2 teachers' pedagogical knowledge base through expert mentoring initiatives. System, 65, 38-48.

Koehler, M.J., \& Mishra, P. (2005). What happens when teachers design educational technology? The development of Technological Pedagogical Content Knowledge. Journal of Educational Computing Research, 32(2), 131-152.

Leinhardt, G., \& Smith, D. A. (1985). Expertise in mathematics instruction: Subject matter knowledge. Journal of Educational Psychology, 77, 247-271.

Li, L. (2017). Social interaction and teacher cognition. Edinburgh University Press.

Li, L. (2020). Language teacher cognition: A sociocultural perspective. Palgrave Macmillan.

Lim, S. (2016). Learning to teach intelligible pronunciation for ASEAN English as a Lingua Franca: A sociocultural investigation of Cambodian pre-service teacher cognition and practice. RELC Journal, 47(3), 313-329.

Mattheoudakis, M. (2007). Tracking changes in pre-service EFL teacher beliefs in Greece: A longitudinal study. Teaching and Teacher Education, 23, 1272-1288.

McAlpine, L., Weston, C., Timmermans, J., Berthiaume, D., \& Fairbank-Roch, G. (2006). Zones: Reconceptualizing teacher thinking in relation to action. Studies in Higher Education, 31(5), 601-615.

McCutchen, D., Abbott, R.D., Green, L.B., Beretvas, S.N., Cox, S., Potter, N.S., ... Gray, A.L. (2002). Beginning literacy: Links among teacher knowledge, teacher practice, and student learning. Journal of Learning Disabilities, 35(1), 69-86.

Meijer, P.C., Verloop, N., \& Beijard, D. (1999). Exploring language teachers' practical knowledge about teaching reading comprehension. Teaching \& Teacher Education, 15, 59-84.

Mohammadabadi, A.M., Ketabi, S., \& Nejadansari, D. (2019). Factors influencing language teacher cognition: An ecological systems study. Studies in Second Language Learning and Teaching, 9(4), 657-680.

Moreland, J., Jones, A., \& Northover, A. (2001). Enhancing teachers' technological knowledge and assessment practices to enhance student learning in technology: A two-year classroom study. Research in Science Education, 31, 155-176.

Mori, R. (2011). Teacher cognition in corrective feedback in Japan. System, 39(4), 451-467.

Nespor, J. (1987). The role of beliefs in the practice of teaching. Journal of Curriculum Studies, 19(4), 317-328.

Ng, W., Nicholas, H., \& Williams, A. (2009). School experience influences on pre-service teachers' evolving beliefs about effective teaching. Teaching and Teacher Education, 26(2), 278-289.

Ngo, X.M. (2018). A sociocultural perspective on second language writing teacher cognition: A Vietnamese teacher's narrative. System, 78, 79-90.

Öztürk, M., \& Yıldırım, A. (2015). English as a Foreign Language instructors' cognitions on language learning processes and factors affecting those cognitions. Education and Science, 40(182), 171-192.

Öztürk, M., \& Yıldırım, A. (2019). Relationships between foreign language teachers' cognitions and actions: Evidence from instructors at tertiary-level. Hacettepe University Journal of Education, 34(1), 145-159.

Pajares, M.F. (1992). Teachers' beliefs and educational research: Cleaning up a messy construct. Review of Educational Research, 62(3), 307-332. 
Ponte, P., Ax, J., Beijaard, D., \& Wubbels, T. (2004). Teachers' development of professional knowledge through action research and the facilitation of this by teacher educators. Teaching and Teacher Education, 20, 571-588.

Richardson, V. (1996). The role of attitudes and beliefs in learning to teach. In J. Sikula, T. J. Buttery \& E. Guyton (Eds.), Handbook of research on teacher education ( $2^{\text {nd }}$ ed.) (pp. 102-119). Macmillan.

Shavelson, R.J., \& Stern, P. (1981). Research on teachers' pedagogical thoughts, judgements and behaviours. Review of Educational Research, 51(4), 455-98.

Short, J. (2009). The art of writing a review article. Journal of Management, 35, 1312-1317.

Shulman, L.S. (1987). Knowledge and teaching: Foundations of the new reform. Harvard Educational Review, 57(1), 1-22.

Sternberg, R.J. (1997). Thinking styles. Cambridge University Press.

Sun, C., Wei, L., \& Young, R.F. (2020). Measuring teacher cognition: Comparing Chinese EFL teachers' implicit and explicit attitudes toward English language teaching methods. Language Teaching Research, 1-29. https://doi.org/10.1177/1362168820903010

Thomas, J.A., \& Pedersen, J.E. (2003). Reforming elementary science teacher preparation: What about extant teaching beliefs? School Science and Mathematics, 103(7), 319-330.

Thompson, A. (1992). Teachers' beliefs and conceptions: A synthesis of the research. In D. Grouws (Ed.), Handbook of research on mathematics teaching and learning (pp. 127-146). Macmillan.

Todd, M., Bannister, P., \& Clegg, S. (2004). Independent inquiry and the undergraduate dissertation: Perceptions and experiences of final-year social science students. Assessment \& Evaluation in Higher Education, 29(3), 335-355.

Verloop, N., Van Driel, J., \& Meijer, P.C. (2001). Teacher knowledge and the knowledge base of teaching. International Journal of Educational Research, 35(5), 441-461.

Walsh, R., \& Wyatt, M. (2014). Contextual factors, methodological principles and teacher cognition. Studies in Second Language Learning and Teaching, 4, 693-718.

Wenden, A. (1999). An introduction to meta-cognitive knowledge and beliefs in language learning: Beyond the basics [Special Issue]. System, 27, 435-441.

Whetten, D.A. (1989). What constitutes a theoretical contribution? The Academy of Management Review, 14, 490-495.

Woods, D. (1996). Teacher cognition in language teaching. Cambridge University Press.

Zeichner, K.M. (1994). Research on teacher thinking and different views of reflective practice in teaching and teacher education. In I. Carlgren, G. Handal, \& S. Vaage (Eds.), Teachers' minds and actions: Research on teachers' thinking and practice (pp. 9-27). The Falmer Press.

Zheng, H. (2009). A review of research on EFL pre-service teachers' beliefs and practices. Journal of Cambridge Studies, 4(1), 73-81. 


\section{TÜRKÇE GENIŞLETILMIŞ ÖZET}

Öğretmenlik, hem bilişsel bir etkinlik hem de sosyal bir davranış olarak karmaşık bir özelliğe sahiptir; bu nedenle, öğretmenlerin sınıftaki alışkanlıklarını ve davranışsal eğilimlerini nasıl geliştirdiğini ve yönettiğini izlemek son derece önemlidir. Öğretmenlerin zihinsel yönetimi uzun süredir eğitim araştırmalarının odak noktası olmuştur, çünkü bu zihinsel yönetimin öğretmen eylemlerini yönlendirdiği bilinmektedir.

Öğretmenlerin öğretmenliğe dair alışkanlıklarının, kişisel, sosyal ve mesleki gelişimlerinin en doğal yansımaları olduğu düşünüldüğünde, bu makalenin merkezinde, öğretmen bilişinin ne olduğu, neden önemli olduğu ve nasıl geliştiği ile ilgili sorular yer almaktadır. Öğretmen bilişini, öğretmenlik alışkanlıklarını geliştirmek ve yönetmek için güçlü bir olgu olarak ele alan bu makalede, kavramsal geliştirme yaklaşımı benimsenmiş ve öğretmen bilişi tarihsel temelleri, kilit bileşenleri, kavramsal boyutları, temel kökenleri ve itici güçleriyle birlikte ele alınarak kapsamlı ve bütüncül bir alanyazın derlemesi sunulmuştur.

Makalede ilk olarak öğretmen bilişinin tarihsel temellerine ve kilit bileşenlerine, ardından öğretmen bilişi üzerine son on yılda yapılmış deneysel çalışmalara yer verilmiştir. Öğretmen bilişinin kavramsal alanlarına ilişkin ise, kırk yılı aşkın bir dönemi kapsayan deneysel ve kuramsal alanyazında yer alan tanımların genişliği ve derinliği üzerine inşa edilmiş üçlü bir model ortaya konulmuştur (bkz Şekil 1; Figure 1). Buna göre, öğretmen bilişi en kapsamlı şekilde ancak şu üç olgu aracillğı̆yla temsil edilebilir: (a) öğretmenlerin inanç sistemi, (b) öğretmenlerin bilgi dağarcığı ve (c) öğretmenlerin düşünce sistemi.

Bir sonraki aşamada, öğretmenlerin kişisel ve mesleki yaşamlarını çevreleyen bağlamsal koşullara odaklanarak, öğretmen bilişinin üç kökeni ve üç itici gücü tartışılmıştır. Bu bağlamda, bu her iki olgu için de birbirine bağlı üç unsur ele alınmıştır (bkz Şekil 2; Figure 2). Öğretmen bilişinin üç temel kökenini, öğretmenlerin geçmiş okul deneyimleri, hizmet-öncesi öğretmen eğitimleri ve hizmet-içi sınıf deneyimleri oluşturmaktadır. Bu üç unsur, öğretmen bilişis ile ilgili alanyazında oldukça geniş bir yer bulmuştur. Sonraki süreçteki öğretmen bilişini geliştiren, şekillendiren veya değiştiren itici güçler ise, sürekli mesleki gelişim, öğretmenler tarafından yürütülen araştırmalar ve lisansüstü eğitim süreçleri şeklinde sıralanmıştır. Bununla birlikte, bu üç unsur öğretmen bilişine ilişkin alanyazında yeterince ele alınmamış veya diğer üç unsur kadar fazla yer bulmamıştır.

Bu makalenin asıl katma değeri, öğretmen bilişini inşa edilme ve eyleme yönelme biçimleri açısından yeniden ele alması ve öğretmen eğitimi için çıkarımlarda bulunmasıdır. Buna göre, ilk açılım olan öğretmen bilişinin inşa edilme yollarına baktığımızda, iki basit yol düşünebiliriz: (1) öğretmenlerin öğretmen olarak yaptıkları uygulamaları yansıttıkları ve kendi tecrübelerini temel alarak kullandıkları deneyimsel yap1; (2) etrafındaki diğer öğretmenleri gözlemleme veya model alma yoluyla oluşturdukları gözlemsel yapı. Her iki şekilde de, biliş inşası öğretmenlerin gerek kendi iç dünyasında gerekse etrafında başkalarıyla girdikleri etkileşimlerde gördükleri, duydukları, okudukları, sordukları, cevapladıkları veya yaptıkları her şeyle ilgilidir.

Öğretmen bilişinin tek başına bireyin iç dünyasından veya yalnızca çevresinden beslenmediğini, her ikisinin etkileşiminden kaynaklanan karmaşık bir özelliğe sahip olduğunu göz önünde bulundurarak, öğretmenlerin hem 'özde oluşturulmuş' hem de 'dışarıdan edinilmiş' bilişleri birlikte ele alınmalı ve değerlendirilmelidir. Bu çerçevede, özde oluşturulmuş öğretmen bilişi, öğretmenin öz-odaklı zihinsel aktivitesinin bir sonucu olarak inşa edilmiş ve dış girdiden bağımsız olabilir. Öte yandan, dışarıdan edinilmiş öğretmen bilişi de önemli bir yere sahiptir, çünkü bu biliş öğretmenlere öğretmenlik uygulamalarında rehberlik edecek yeni alternatifler veya yaklaşımlar gösterme olasıllı̆̆ 1 taşır. Bu şekilde, öğretmenler yeni bilişleri benimserler veya mevcut bilişleriyle yüzleşirler. Sonuç olarak, onları eleştirel bir şekilde analiz eder ve yeni bakış açılarına dönüştürürler. Bilişler, içsel durumlar ve 
dış girdiler arasında aracılık edebildiği için, bu süreç, öğretmen bilişini inşa etmenin veya yeniden inşa etmenin temel bir aşaması olarak görülür ve özde oluşturulmuş ve dışarıdan edinilmiş bilişler arasındaki kesişimi ifade eder.

Öğretmen bilişini öğretmenlerin alışkanlıklarını ve eylemlerini yönetmek için güçlü bir olgu olarak kavramsallaştırdığımızda ve bilişlerin davranış düzenleme işlevini göz önünde bulundurduğumuzda, ikinci önemli açılım, eyleme yönelme biçimleri açısından bilişlerin işlevsel, işlevsel olmayan ve durumsal olarak sinıflandirılmasidır.

İşlevsel bilişler özünde eyleme uygun bir şekilde aktarılabilen bilişlerdir. Başka bir deyişle, uygulama odaklıdırlar ve bu yönelim, bilişlerin davranışları düzenleme kapasitesini ifade eder. Bilişlerin işlevsel bir şekilde eylemlere aktarılmasında, öğretmenlerin inandıkları veya düşündükleri biçimde hareket etmesi veya davranması beklenir. Ve böylece, biliş-eylem arasındaki uyumsuzluk olasılığ 1 ortadan kalkmış olur. Bununla birlikte, işlevsel olmayan bilişler, davranış düzenleme veya değiştirme konusunda etkisiz olduğu için söz konusu uyumsuzluğun yaşanması olasıdır. İşlevsel olmayan bilişler, öğretmenlerin istendik biçimde performans sergileme isteğini ve çabasını azaltabileceğinden veya inandıklarını yerine getirmelerini engelleyebileceğinden, biliş ve eylem arasındaki boşluk büyür. $\mathrm{Bu}$ nedenle, öğretmenin bilişinin eyleme dönüşecek kadar ikna edici olması gerekir ki bu da bilişin davranış düzenleme işlevini ortaya koyar.

Şekil 3'te (Figure 3) görüldüğ̈̈ gibi, işlevsel ve işlevsel olmayan bilişlerin kesiştiği alan ise durumsal bilişler alanıdır. Bazen öğretmenlerin duyumları, algıları ve dikkatleri farklı zamanlarda farklı koşullara bağlı olarak değişkenlik gösterebilir ve bilişin eyleme aktarılması çeşitli durumlara bağlı olabilir. Bu noktada, çevresel (dış) dinamizm ve kişisel (iç) dinamizm, öğretmenlerin karar verme, akıl yürütme ve muhakeme becerilerinin iki kritik bileşeni olarak ortaya çıkar. Çevresel dinamizm eğitim ortamlarında gözlenen olası farklılıkları ifade ederken, kişisel dinamizm aynı öğretmen içinde farklı zamanlarda veya farklı durumlarda gözlenebilen olası farklılıkları ifade eder. İster her iki dinamizmi birbirinden bağımsız olarak ister bir arada düşünelim, öğretmenlerin kimi bilişlerinin durumsal olması olağandır.

Son olarak, biliş ve eylem arasındaki karş1lıklı etkileşim göz önünde bulundurularak, öğretmen bilişi konulu eğitim araştırmalarının alana sağlayacağı katkılar dört başlık altında özetlenebilir: (1) öğretmen eğitimi programlarını ve içeriğini belirlemede kullanılacak veriler sunma; (2) öğretmen eğitiminde kullanılan öğretim yöntemleri ve teknikleri üzerine düşünebilmeleri için öğretmen eğitimcilerine iç görü sağlama; (3) öğretmen eğitimiyle ilgili eğitim politikaları oluşturma ve yönetme; ve (4) öğretmenlerin öğretmenlik biçimlerine yönelik iç gözlemlerini ve yansıtıcı becerilerini geliştirme. 